\title{
PERBANDINGAN PRODUKSI UBIKAYU (Manihot esculenta Crantz) AKIBAT PENAMBAHAN PUPUK KCI DAN PEMBERIAN PUPUK MIKRO SAAT PANEN 7 BULAN
}

\author{
COMPARISON OF CASSAVA (Manihot esculenta Crantz) YIELD \\ APPLIED BY KCl AND MICRO HARVEST AT 7 MONTH
}

\author{
Muhammad Fajrin Najib', Kukuh Setiawan ${ }^{2}$, M. Syamsoel Hadi ${ }^{3}$, Erwin Yuliadi ${ }^{4}$ \\ Jurusan Agroteknologi, Fakultas Pertanian, Universitas Lampung \\ E-mail: muhammadfajrinnajib@gmail.com
}

Dikirim 19 September 2020, Direvisi 12 November 2020, Disetujui 24 November 2020

\begin{abstract}
Abstrak: Penelitian ini bertujuan untuk mengevaluasi produksi ubikayu akibat penambahan unsur hara kalium dan unsur hara mikro saat panen 7 bulan. Lokasi penelitian di lahan kering bertipe tanah lempung berpasir, Desa Sukanegara, Tanjung Bintang, Lampung Selatan dari April sampai Februari 2018. Klon yang digunakan yaitu Klon BW-1 dengan jarak tanam 1m x 1m. Perlakuan disusun secara faktorial (2x2) dalam Rancangan Kelompok Teracak Lengkap (RKTL). Setiap perlakuan diulang tiga kali yang digunakan sebagai kelompok. Faktor pertama 2 taraf dosis pupuk KCl yaitu $200 \mathrm{~kg} \mathrm{ha}^{-1}$ dan $300 \mathrm{~kg} \mathrm{ha}^{-1}$. Faktor kedua 2 taraf pupuk mikro yaitu $0 \mathrm{~kg} \mathrm{ha}^{-1} \mathrm{dan}$ $20 \mathrm{~kg} \mathrm{ha}^{-1}$. Variabel yang diamati yaitu tinggi tanaman, jumlah daun, bobot kering batang, bobot kering petiol, bobot kering daun, jumlah ubi, panjang ubi, diameter ubi, bobot ubi per tanaman dan kadar pati. Data dianalisis menggunakan aplikasi SAS 9.0. dengan taraf nyata 5\%. Hasil penelitian menunjukan bahwa penambahan $300 \mathrm{~kg}$ $\mathrm{KCl} \mathrm{ha}{ }^{-1}$ menghasilkan rata-rata bobot ubi per tanaman $(1.983,3 \mathrm{~g}$ ) yang lebih besar dibandingkan $200 \mathrm{~kg} \mathrm{KCl} \mathrm{ha}$ ${ }^{1}$ rata-rata bobot ubi per tanaman $(1.450,0 \mathrm{~g})$, begitu juga dengan panjang ubi yang diberi $300 \mathrm{~kg} \mathrm{KCl} \mathrm{ha}{ }^{-1}$ menghasilkan rata-rata panjang ubi $25,15 \pm 10,78 \mathrm{~cm}$ yang lebih panjang dibandingkan $200 \mathrm{~kg} \mathrm{KCl} \mathrm{ha}^{-1}$ rata-rata panjang ubi $21,27 \pm 7,38 \mathrm{~cm}$. Selajutnya pemberian $20 \mathrm{~kg}$ pupuk mikro ha- ${ }^{-1}$ mampu menghasilkan rata-rata bobot ubi per tanaman $(1.966,70 \mathrm{~g})$ yang lebih besar dibandingkan tanpa aplikasi mikro $(1.466,70 \mathrm{~g})$ begitu juga dengan diameter ubi 7 BST yang diberi $20 \mathrm{~kg}$ pupuk mikro ha- ${ }^{-1}$ menghasilkan rata-rata diameter 3,6 $\pm 0,8 \mathrm{~cm}$ yang lebih besar dibandingkan tanpa aplikasi pupuk mikro rata-rata diameter ubi 3,07 $\pm 0,7 \mathrm{~cm}$. Namun tidak ada interaksi antara aplikasi kedua dosis pupuk $\mathrm{KCl}$ dengan kedua dosis pupuk mikro terhadap komponen ubi.
\end{abstract}

Kata kunci: lahan kering, pupuk, mikro, $\mathrm{KCl}$, produksi, ubikayu.

Abstract: This experiment aims to evaluate the production of cassava due to the application of potassium and micro nutrients at harvest 7 months. The research location was on sandy loam, Sukanegara Village, Tanjung Bintang, South Lampung from April to February 2018. The clone used was Clone BW-1 with a spacing of $1 m x$ $1 \mathrm{~m}$. The experiment was arranged factorially $(2 \times 2)$ in a completely randomized block design (CRBD). Each treatment was repeated three times which were used as blocks. The first factor were 2 levels of KCl fertilizer dosage, namely $200 \mathrm{~kg} \mathrm{ha}^{-1}$ and $300 \mathrm{~kg} \mathrm{ha}^{-1}$. The second factor was 2 levels of micro fertilizer, namely $0 \mathrm{~kg} \mathrm{ha} \mathrm{g}^{-1}$ and $20 \mathrm{~kg} \mathrm{ha}^{-1}$. The variables observed were plant height, leaf number, stem dry weight, petiol dry weight, leaf dry weight, tuber number, tuber length, tuber diameter, tuber weight per plant and starch content. Data were analyzed by using SAS 9.0 subjected to analysis of variance and least significant difference (LSD) at 5\% level. The results showed that the application of $300 \mathrm{~kg} \mathrm{KCl} \mathrm{ha-1}$ resulted in a greater average of tuber weight per plant $(1.983 .3 \mathrm{~g})$ compared to $200 \mathrm{~kg} \mathrm{KCl} \mathrm{ha-1}(1.450 .0 \mathrm{~g})$, also tuber length given $300 \mathrm{~kg}$ of $\mathrm{KCl} \mathrm{ha} a^{-1}$ yield an average of tuber

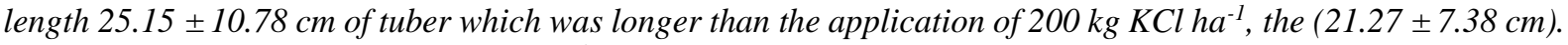
Application of $20 \mathrm{~kg}$ of micro fertilizer ha-1 was able to produce a larger average of tuber weight $(1,966.70 \mathrm{~g})$ than without micro fertilizer application $(1,466.70 \mathrm{~g})$. In addition the tuber diameter at 7 MAP given $20 \mathrm{~kg}$ of micro fertilizer hat produced an average of tuber diameter of 3,6 $\pm 0,8 \mathrm{~cm}$ which was greater than without the application of micro-fertilizers, $(3,07 \pm 0,7 \mathrm{~cm})$. This experiment showed that effect of $\mathrm{KCl}$ application was not influenced by application of micro fertilizer.

Keywords: cassava, production, $\mathrm{KCl}$, micro, fertilizer, dry land. 


\section{PENDAHULUAN}

Indonesia merupakan salah satu negara produsen penghasil ubikayu yang menempati urutan keempat di dunia setelah Brazil, Thailand dan Nigeria. Produksi ubikayu di Indonesia pada 2016 mencapai 20.744.674 ton. Tingginya produksi ubikayu Indonesia didorong oleh luas area panen. Luas panen ubikayu sebesar 867.495 hektar membuat Indonesia menempati urutan ke-5 negara sentra luas panen dunia (FAO, 2017). Produksi ubikayu di Indonesia terkonsentrasi di 8 (delapan) provinsi dengan kontribusi produksi sebesar 91,21\%. Provinsi Lampung cukup dominan di urutan pertama disusul Jawa Tengah, Jawa Timur, Jawa Barat, Sumatra Utara, DI. Yogyakarta, Nusa Tenggara Timur, dan Sulawesi Selatan (Pusdatin, 2016). Provinsi Lampung menjadi salah satu daerah produsen utama ubikayu di Indonesia. Selama periode 20122016, Lampung memberikan kontribusi sebesar $33,93 \%$ terhadap produksi nasional dengan rata-rata produksi mencapai 7.741 .948 ton. Lampung juga memberikan kontribusi luas areal panen sebesar $27,71 \%$ dari 34 provinsi. Tingginya luas panen dan produksi ubikayu didukung oleh tingkat kesesuaian lahan di Lampung terhadap ubikayu (Pusdatin, 2016).

Ubikayu merupakan salah satu tanaman penting di Indonesia. Ubikayu adalah salah satu bahan pangan pengganti beras yang berperan penting dalam menopang ketahanan pangan di Indonesia. Komoditas tersebut merupakan bahan pangan pokok ketiga di Indonesia setelah padi dan jagung. Selain sebagai bahan pangan, ubikayu juga digunakan sebagai bahan baku industri dan pakan ternak. Ubikayu termasuk komoditas pangan yang sudah lama dibudidayakan. Ubikayu memiliki keunggulan diantaranya mengandung nutrisi tinggi dan lengkap serta banyak manfaatnya. Kandungan setiap 100 gram ubikayu berupa energi sebesar 146 kalori, 62,8 g air, $40 \mathrm{mg}$ fosfor, 34,7 g karbohidrat, $33 \mathrm{mg}$ kalsium, 1,2 g protein, 0,7 $\mathrm{mg}$ besi, 0,3 g lemak, 0,01 $\mathrm{mg}$ vitamin B1 dan $30 \mathrm{mg}$ vitamin C. Keberagaman kandungan nutrisi yang ada pada ubikayu mendorong terus bertambahnya penggunaan ubikayu di berbagai sektor, termasuk industri dan kimia (BBPPTP, 2012). Besarnya potensi ubikayu dalam berbagai pemanfaatan mendorong peningkatan permintaan terhadap ubikayu. Berdasarkan perhitungan proyeksi permintaan ubikayu yang dilakukan oleh Pusat Data dan Informasi Pertanian, tahun 2015-2020 akan mengalami peningkatan rata-rata sebesar $2,15 \%$ per tahun. Untuk memenuhi permintaan ubikayu setiap tahunnya perlu dilakukan upaya peningkatan hasil produksi (Pusdatin, 2016). Usaha peningkatan hasil produksi ubikayu menemui berbagai macam kendala. Kendala yang sering ditemui yaitu menurunnya luas lahan produksi, ketersediaan sarana produksi bermutu dan kualitas sumber daya manusia. Selama periode 2012-2016, perkembangan luas panen produktif ubikayu Indonesia cenderung mengalami penurunan yaitu ratarata 6,38\% per tahun (Pusdatin, 2016).

Menurut Setiawan et al. (2017), pemilihan bibit yang tidak tepat, pemupukan yang hanya menggunakan pupuk dasar NPK sementara banyak unsur hara lain yang dibutuhkan tanaman, serta kebiasaan petani sering memanen ubikayu pada umur relatif muda yaitu sekitar 7-8 bulan setelah tanam (BST) bahkan ada yang masih berumur 6 BST. Hal tersebut mempengaruhi kuantitas dan kualitas ubikayu yang dihasilkan, serta berpengaruh terhadap harga yang ditawarkan. Peningkatan produksi untuk mengoptimalkan hasil dari lahan yang sudah ada salah satunya ialah dengan cara pemupukan. Selama ini pemahaman petani ubikayu dalam melakukan pemupukan hanya sebatas memberikan asupan unsur hara berupa Urea, $\mathrm{KCl}$ dan TSP. Sedangkan untuk mendapatkan tingkat hasil tinggi, tanaman memerlukan semua hara dalam 
jumlah banyak dan dalam perbandingan yang tetap proporsional. Kebutuhan hara harus dipenuhi berdasarkan peran serta kemampuan tanaman dalam menyerap hara tersebut. Unsur hara menjadi komponen yang sangat penting dalam upaya peningkatan produksi ubikayu. Tanaman membutuhkan berbagai macam unsur hara selama siklus hidupnya. Unsur hara dapat diperoleh melalui pemupukan, baik pupuk organik maupun anorganik. Terdapat unsur hara yang ketersediaannya harus tercukupi bagi tanaman serta fungsinya tidak dapat digantikan oleh unsur lain disebut unsur hara esensial. Unsur hara esensial ini terbagi atas 2 kelompok yaitu unsur hara makro adalah unsur hara yang dibutuhkan tanaman dalam jumlah yang banyak, dan unsur hara mikro yang dibutuhkan dalam jumlah yang sedikit (Sulistianingrum, 2013).

Tanaman ubikayu menyerap unsur hara dalam tanah dengan jumlah yang cukup tinggi. Salah satu unsur hara yang banyak diserap adalah kalium (K), kebutuhan kalium bahkan melebihi kebutuhan nitrogen (N) (Subandi, 2013). Unsur kalium berperan dalam proses pertumbuhan dan pembentukan ubi, sehingga dibutuhkan pemberian unsur hara $\mathrm{K}$ dalam jumlah banyak agar tanaman dapat berproduksi secara optimum. Oleh sebab itu, perlu dilakukan pemupukan untuk menambah dan mengembalikan unsur hara yang telah terserap dan terbawa tanaman saat panen. Unsur hara mikro seperti $\mathrm{Fe}, \mathrm{Cu}, \mathrm{Zn}, \mathrm{Mn}$, Mo, $\mathrm{B}$ dan $\mathrm{Cl}$ juga dibutuhkan untuk pertumbuhan akan tetapi, diperlukan dalam jumlah sedikit. Masalah kekurangan unsur hara mikro terjadi karena petani tidak menambahkan unsur hara tersebut dan hanya sebatas melakukan pemupukan Urea, $\mathrm{KCl}$ dan TSP, sedangkan unsur mikro juga diperlukan. Secara umum fungsi unsur hara mikro adalah sebagai penyusun jaringan tanaman, sebagai katalisator (stimulant), membantu mengatur kadar asam, mempengaruhi nilai osmotik tanaman ujung akar. Kekurangan unsur hara mikro tentunya akan menyebabkan pertumbuhan ubikayu terganggu serta produksi juga tidak maksimal (Sudarmi, 2013). Oleh sebab itu, penelitian ini dilakukan untuk mengevaluasi penambahan unsur kalium dan pemberian pupuk mikro terhadap pertumbuhan dan hasil produksi tanaman ubikayu yang dipanen umur 7 bulan.

\section{TINJAUAN PUSTAKA}

\section{Syarat Tumbuh Tanaman Ubikayu}

Ubikayu merupakan salah satu tanaman tropis yang memiliki daya adaptasi yang tinggi, termasuk dapat bertahan hidup di lingkungan yang kering. Namun, ubikayu tetap membutuhkan kondisi lingkungan optimum di dalam maupun permukaan tanah untuk pertumbuhan dan perkembangannya. Kondisi optimum di lingkungan pertumbuhan akan mendorong ubikayu untuk menghasilkan umbi yang baik. Keadaan iklim, jenis tanah dan pengolahan tanah juga akan berpengaruh pada hasil ubikayu. Ubikayu dikembangkan di wilayah $30^{\circ} \mathrm{LU}$ dan $30^{\circ} \mathrm{LS}$. Suhu yang dikehendaki untuk perkembangan ubikayu adalah $18^{\circ}$ $35^{\circ} \mathrm{C}$, suhu yang lebih rendah akan mengakibatkan terhambatnya pertumbuhan. Kelembaban yang dibutuhkan adalah $65 \%$. Daerah yang ideal untuk pertumbuhan ubikayu adalah di dataran rendah pada ketinggian $150 \mathrm{~m}$ dpl dengan suhu $25-27^{\circ} \mathrm{C}$. Beberapa jenis ubikayu juga ada yang dapat tumbuh di dataran tinggi pada ketinggian di atas $1.500 \mathrm{~m}$ dpl. Meskipun memiliki daya adaptasi tinggi terhadap daerah kering, ubikayu tetap membutuhkan curah hujan yang cukup. Curah hujan minimum untuk pertumbuhan ubikayu adalah $500 \mathrm{~mm}$ per tahun dan curah hujan maksimum yang masih dapat ditolerir untuk pertumbuhan ubikayu adalah $5.000 \mathrm{~mm}$ per tahun. Sedangkan kondisi curah hujan optimum yang ideal berkisar antara 760-1.015 $\mathrm{mm}$ per tahun. Tingginya curah hujan akan 
berdampak pada meningkatnya serangan patogen apabila drainase dan sanitasi kebun yang kurang baik. Ubikayu membutuhkan struktur tanah yang gembur untuk perkembangan dan pembentukan ubi. Pada dasarnya ubikayu dapat tumbuh di berbagai jenis tanah. Sebagian besar daerah yang ditumbuhi ubikayu memiliki jenis tanah alluvial, latosol dan padsolik. Beberapa daerah dengan jenis tanah Mediteran, Grumusol dan Andosol juga ditumbuhi ubikayu. Kemasaman tanah $(\mathrm{pH})$ yang dibutuhkan ubikayu adalah minimal 5 (Sundari, 2010).

\section{Kalium}

Kalium (K) merupakan unsur hara makro esensial yang diperlukan dalam jumlah besar terutama untuk tanaman ubikayu. Keberadaannya unsur $\mathrm{K}$ tidak dapat digantikan oleh unsur hara lainnya. Kalium berperan secara langsung dalam menentukan hasil produksi tanaman. Peran kalium di antaranya menjaga tekanan turgor sel, mengatur menutup dan membukanya stomata, translokasi dan akumulasi karbohidrat. Gejala yang ditimbulkan oleh kekurangan unsur kalium di antaranya pertumbuhan terhambat dan banyak membentuk cabang, ruas memendek, klorosis pada tepi daun dan kemudian mengering. Kadar kritis kandungan K-dd untuk tanaman ubikayu adalah sekitar 0,15 me/100 g (Saleh et al., 2016). Menurut Subandi (2013) tanaman yang cukup K akan lebih tahan serangan penyakit sebab meningkatnya pembentukan senyawa fenol yang bersifat fungisida dan menurunnya kandungan $\mathrm{N}$ anorganik dalam jaringan tanaman. Pemberian $\mathrm{K}$ yang cukup pula merupakan salah satu upaya mengatasi keracunan besi pada tanaman padi. Tanaman padi yang kekurangan $\mathrm{K}$, sel-sel akarnya akan mengeluarkan eksudat dan kemampuan oksidasinya menurun. Kondisi ini akan meningkatkan suasana reduktif di daerah perakaran yang akhirnya meningkatkan kelarutan $\mathrm{Fe}$ karena ion ferri $\left(\mathrm{Fe}^{3+}\right)$ yang sukar larut berubah menjadi ion ferro $\left(\mathrm{Fe}^{2+}\right)$ yang mudah larut. Mengingat banyaknya peran unsur kalium maka diperlukan penambahan dosis kalium untuk mendapatkan hasil yang maksimal.

\section{Peranan Unsur Hara Mikro}

Terdapat unsur hara esensial yang dibutuhkan tanaman dalam jumlah yang relatif sedikit yaitu unsur hara mikro. Unsur hara mikro mempunyai fungsi yang spesifik dalam pertumbuhan dan perkembangan tanaman serta fungsinya tidak dapat digantikan secara sempurna oleh unsur hara lain, tetapi bila berlebihan akan menjadi racun bagi tanaman tersebut. Unsur hara mikro antara lain Besi (Fe), Tembaga $(\mathrm{Cu})$, Seng (Zn), Mangan (Mn), Molibdenum (Mo), Boron (B), dan Klor (Cl) (Sudarmi, 2013). Unsur hara mikro memiliki peran penting seperti unsur hara makro, walaupun kebutuhan akan unsur hara mikro relatif rendah. Unsur hara mikro berperan dalam metabolisme yang berdampak pada pertumbuhan dan perkembangan tanaman yang menentukan kualitas dan kuantitas ubikayu. Sebagai contoh apabila tanaman kekurangan unsur hara mikro $\mathrm{Fe}, \mathrm{Mn}, \mathrm{Cu}$, Zn, Mo, dan B berdampak pada daun tanaman yang akan mengalami klorosis, pertumbuhan tanaman menjadi terhambat, dan pertumbuhan terhambat pada ujung akar (Sudarmi, 2013).

\section{(1). Besi (Fe)}

Besi berperan sebagai penyusun klorofil, protein, enzim, dan berperan dalam perkembangan kloroplas. Sebagai penyusun klorofil ketersedian Fe berkorelasi dan kadar klorofil dalam tanaman. Fungi lain Fe ialah sebagai pelaksana pemindahan elektron dalam proses metabolisme. Proses tersebut misalnya reduksi $\mathrm{N}_{2}$, redoktase sulfat, redoktase nitrat. Kekurangan $\mathrm{Fe}$ menyebabkan terhambatnya pembentukan klorofil dan akhirnya penyusunan protein juga tidak sempurna. Defisiensi Fe 
menyebabkan kenaikan kadar asam amino pada daun dan penurunan ribosom secara drastis (Rosmarkam dan Yuwono, 2002).

\section{(2). Tembaga $(\mathrm{Cu})$}

Tembanga berperan dalam mengaktifkan enzim sitokrom-okidasi, askorbit-okidasi, asam butirat-fenolase, dan laktase. $\mathrm{Cu}$ juga berperan dalam metabolisme protein dan karbohidrat. Oleh karena itu, apabila tanaman kekuranan $\mathrm{Cu}$ sintesis protein terganggu, maka protein yang ada jadi larut. $\mathrm{Cu}$ merupakan kofaktor sintesis enzim dan juga berpengaruh pada RNA dan DNA, dalam organ yang paling muda tempat sintesis yang paling aktif, kadar DNA rendah bila tanaman tersebut kahat $\mathrm{Cu}$. Metabolisme karbohidrat juga terganggu bila tanaman tersebut kahat $\mathrm{Cu}$ (Rosmarkam dan Yuwono, 2002).

\section{(3). Seng (Zn)}

Seng merupakan salah satu unsur hara mikro yang sangat penting bagi pertumbuhan tanaman. Seng diserap tanaman dalam bentuk ion $\mathrm{Zn}^{2+}$ dan berperan penting dalam proses sintesis hormon tumbuh (auksin) dan proses sintesis protein. Kekurangan unsur $\mathrm{Zn}$ dapat menghambat pertumbuhan dan produksi tanaman (Marshcner, 1986). Sarwar (2011), mengemukakan unsur $\mathrm{Zn}$ juga dapat meningkatkan kesehatan dan resistensi terhadap serangan organisme penggangu tanaman.

\section{(4). Mangan (Mn)}

Mangan dapat diserap dalam bentuk ion $\mathrm{Mn}^{2+}$ seperti hara mikro lainnya, dianggap dapat diserap dalam bentuk kompleks khelat. Mangan berperan dalam pembentukan klorofil, membantu proses fotosintesis, sebagai katalisator berbagai enzim yang berperan dalam proses perombakan karbohidrat dan metabolisme nitrogen. Gejala kekurangan unsur mangan (Mn) pada tanaman tidak dapat diketahui secara langsung tanpa membawa sampel daun atau tanah ke laboratorium (Sudarmi 2013).

\section{(5). Molibdenum (Mo)}

Molibdenum diserap dalam bentuk anion divalen $\left(\mathrm{MoO}_{4}{ }^{2-}\right)$ dan berperan sebagai bagian dari enzim nitrat reduktase yang mereduksi ion nitrat menjadi ion nitrit (Salisbury dan Ross, 1995). Rosmarkam dan Yuwono (2002), menyatakan bahwa fungsi Mo dalam tanaman adalah mengaktifkan enzim nitrogenase, nitrat reduktase dan xantine okidase. Kekurangan Mo dapat menghambat pertumbuhan, daun menjadi pucat dan mati, pembentukan bunga terlambat dan pembentukan benang sari berkurang.

\section{(6). Boron (B)}

Boron merupakan salah satu unsur hara mikro esensial bagi tanaman. Peran boron pada tanaman antara lain metabolisme asam amino, karbohidrat dan protein. Ketersedian boron memudahkan pengikatan molekul glukosa dan fruktosa menjadi selulosa untuk mempertebal dinding sel sehingga tanaman akan lebih tahan terhadap serangan hama dan penyakit. Selain itu, boron juga berfungsi sebagai aktivator maupun inaktivator hormon auksin dalam pembelahan dan pembesaran sel (Marshcner, 1986).

\section{(7). Klor (Cl)}

Klor merupakan unsur hara mikro yang berfungsi sebagai pemindah hara tanaman. Ion $\mathrm{Cl}^{-}$mempunyai peranan penggelembungan protoplasma dan meningkatkan permealibilitas. Peranan terhadap turgor sel hampir sama dengan ion $\mathrm{K}$, yakni meningkatkan tekanan osmosis sel. Klor juga berperan terhadap tata air sel, mencegah kehilangan air yang tidak seimbang. Makin tinggi kadar $\mathrm{Cl}$ dalam tanaman dapat mengurangi resiko kekeringan atau kelayuan dan penguapan terhambat. Klor dapat memperbaiki penyerapan ion lain, misalnya ion $\mathrm{K}$ dan $\mathrm{Ca}$. Gejala defisiensi $\mathrm{Cl}$ adalah akar tanaman tidak dapat berkembang dengan baik, daun muda mengalami bercak klorosis dan 
nekrosis. Gejala defisiensi $\mathrm{Cl}$ mirip dengan gejala defisiensi unsur hara lainnya, sehingga sukar dibedakan (Rosmarkam dan Yuwono, 2002).

\section{METODE PENELITIAN}

Penelitian ini dilakukan di Desa Sukanegara, Kecamatan Tanjung Bintang, Kabupaten Lampung Selatan. Waktu penelitan dilaksanakan pada September 2017 sampai dengan Agustus 2018 di lahan bertipe tanah lempung berpasir. Alat yang digunakan dalam penelitian ini ialah traktor dan perlengkapan bajak, golok, ember, patok, cangkul, koret, alat tugal, meteran, label sampel, sabit, pisau, jangka sorong, timbangan digital, amplop, plastik, karung, alat tulis, dan timbangan kadar pati Thai Sang Metric co. Ltd. Sedangkan bahan yang digunakan ialah stek tanaman ubikayu klon BW-1, pupuk $200 \mathrm{~kg}$ Urea ha $^{-1}, 150 \mathrm{~kg}$ TSP $\mathrm{ha}^{-1}, 200 \mathrm{~kg} \mathrm{KCl} \mathrm{ha}^{-1}$ dan $300 \mathrm{~kg} \mathrm{KCl} \mathrm{ha}{ }^{-1}$ serta $20 \mathrm{~kg}$ pupuk mikro ha-1 ${ }^{-1}$ Pupuk mikro yang digunakan bermerek dagang ZincMicro yang mengandung unsur hara mikro terdiri dari : 5880,31 ppm Fe; 482,61 ppm Mn; 198,10 ppm Cu; 1368 ppm Zn; 3,34 ppm Co; 4,69 ppm Mo; 48 ppm B (Berdasarkan hasil analisis Laboratarium Universitas Padjadjaran 2011).

Pelaksanaan penelitian dimulai dari pengolahan tanah dengan membersihkan lahan dari sisa-sisa tanaman sebelumnya. Setelah itu, lahan diolah dengan menggunakan bajak mesin dan peralatan budidaya lainnya. Lahan yang digunakan merupakan lahan tadah hujan yang pada musim tanam sebelumnya ditanam singkong. Pembajakan dilakukan dua kali dengan jarak kurang lebih satu minggu setelah pembajakkan pertama. Tanah yang telah diolah tersebut kemudian dilakukan pengukuran atau diploting seluas $3.120 \mathrm{~m}^{2}$ lalu dibuat guludan dengan lebar 2 meter dan panjang 80 meter serta jarak antar guludan atau parit 1 meter didapatkan total 12 guludan. Setelah itu lahan dibagi menjadi 12 petak percobaan dimana setiap satu petak percobaan terdapat 160 lubang tanaman ubikayu.

Pada penelitian ini digunakan bibit stek batang ubikayu klon BW-1 yang berasal dari tanaman sebelumnnya. Stek batang tersebut berukuran panjang rata-rata $25 \mathrm{~cm}$. Penanaman stek batang ubikayu dilakukan secara monokultur dengan sistem double row. Sistem tanam double row adalah membuat baris ganda dalam satu guludan, jarak tanaman dalam satu guludan adalah 100x $100 \mathrm{~cm}$ dan jarak tanaman antarguludan 200x100cm sehingga didapatkan total populasi sebanyak 1.920 tanaman untuk lahan seluas $3.120 \mathrm{~m}^{2}$. Bibit ditanam dengan cara menancapkan stek secara vertikal pada kedalaman 5 sampai $10 \mathrm{~cm}$ atau sepertiga panjang batang masuk ke dalam tanam tanah dengan arah mata tunas menghadap ke atas.

Pemupukan dengan memberikan pupuk anorganik yaitu $200 \mathrm{~kg}$ Urea ha-1, $150 \mathrm{~kg}$ TSP ha ${ }^{-1}, 200 \mathrm{~kg} \mathrm{KCl} \mathrm{ha}^{-1}$ dan $300 \mathrm{~kg} \mathrm{KCl}$ ha $^{-1}$ serta $20 \mathrm{~kg}$ pupuk mikro $\mathrm{ha}^{-1}$. Pemupukan ubikayu dilakukan sebanyak 2 kali, yaitu pemupukan awal pada fase vegetatif yang dilakukan 1 bulan setelah tanam (BST). Pada pemupukan pertama semua tanaman dipupuk dengan $200 \mathrm{~kg}$ Urea $\mathrm{ha}^{-1}$ (32,5 g/tanaman), $150 \mathrm{~kg} \mathrm{TSP} \mathrm{ha}^{-1}(24,4$ $\mathrm{g} /$ tanaman $), \quad 200 \mathrm{~kg} \mathrm{KCl} \quad \mathrm{ha}^{-1} \quad(32,5$ $\mathrm{g} /$ tanaman). Pemupukan kedua dilakukan pada fase generatif sekitar 4 BST, pemupukan ini merupakan lanjutan untuk perlakuan dalam penelitian ini. Pupuk yang digunakan yaitu $100 \mathrm{~kg} \mathrm{KCl} \mathrm{ha}^{-1}$ dan $20 \mathrm{~kg}$ pupuk mikro ha-1. Berdasarkan luas lahan untuk perlakuan dan dosis yang diberikan kebutuhan pupuk untuk penelitian ini adalah $15,6 \mathrm{~kg} \mathrm{KCl}(16,25 \mathrm{~g} / \mathrm{tanaman})$ dan $3,12 \mathrm{~kg}$ pupuk mikro $(3,25 \mathrm{~g} / \operatorname{tanaman})$. Proses pemberian pupuk dilakukan dengan mencampur pupuk $\mathrm{KCl}$ dan pupuk mikro dalam satu ember dan diaduk sampai 
homogen, kemudian membuat takaran pupuk ukuran volume $18,72 \mathrm{~g}$, pupuk diberikan dengan cara ditugal berjarak 5 sampai $10 \mathrm{~cm}$ dari tanaman ubikayu.

Pemeliharaan meliputi penyulaman dan pengendalian gulma. Penyulaman dilakukan setelah tanaman ubikayu berumur satu sampai dua minggu setelah tanam. Penyulaman dilakukan cara mengganti stek yang tidak tumbuh atau abnormal dengan stek baru. Pengendalian gulma dilakukan apabila gulma sudah mengganggu pertumbuhan tanaman. Pengendalian gulma dilakukan secara kimiawi menggunakan herbisida bermerek dagang Gramoxone 276 SL dengan bahan aktif Paraquat Diklorida, dosis yang digunakan $7 \mathrm{ml} / \mathrm{liter}$ air. Pada penelitian ini pemanenan dilakukan pada umur 7 BST. Pada umur 7 BST dilakukan panen secara keseluruhan. Variabel pengamatan pada penelitian ini yaitu (1). Tinggi tanaman $(\mathrm{cm})$, Pengukuran tinggi tanaman dilakukan dengan cara mengukur tinggi semua batang per tanaman, pengukuran dimulai dari pangkal tunas yang tumbuh pada stek batang tanaman ubikayu hingga titik tumbuh atau pucuk daun terbaru menggunakan meteran roll. Pengukuran tinggi tanaman dilakukan sebulan sekali mulai pada umur 4 BST sampai 7 BST. (2). Jumlah daun (helai), Penghitungan jumlah daun dilakukan dengan cara menghitung seluruh daun yang telah terbuka secara sempurna pada setiap batang per tanaman. Perhitungan jumlah daun dilakukan sebulan sekali mulai pada umur 4 BST sampai 7 BST. (3). Bobot kering batang, petio; dan daun (g), bobot kering batang,petiol dan daun didapat dari batang, petiol, dan daun yang telah dipisahkan dan dikeringanginkan selama 1 hari setelah itu, dikeringkan dalam oven pada suhu $70^{\circ} \mathrm{C}$ selama kurang lebih 3 hari, kemudian ditimbang menggunakan timbangan elektrik. Penimbangan bobot brangkasan batang dilakukan ketika tanaman ubikayu berumur 7 BST. (4). Bobot segar ubi per tanaman (g), Pengukuran bobot segar ubi dilakukan dengan cara menimbang seluruh ubi per tanaman yang ada pada setiap sampel. Penimbangan bobot ubi dilakukan menggunakan timbangan elektrik ketika tanaman ubikayu berumur 7 BST. (5) Bobot kulit tanpa ubi (g), panjang ubi (cm), diameter ubi (mm), jumlah ubi (buah), dan kadar pati (\%). Pengukuran komponen ubi dilakukan pada saat umur 7 BST atau pada saat dilakukan pemanenan.

Perlakuan dalam penelitian ini akan disusun secara faktorial $2 \times 2$ dalam Rancangan Kelompok Teracak Lengkap (RKTL). Pelaksanaan penelitian di lapang disusun secara Strip-Plots dengan faktor A adalah pupuk $200 \mathrm{~kg} \mathrm{KCl} \mathrm{ha}{ }^{-1}$ (K1) dan pupuk $300 \mathrm{~kg} \mathrm{KCl} \mathrm{ha}^{-1}$ (K2), faktor B tanpa pupuk mikro (M0) dan menggunakan pupuk mikro (M1).

Kombinasi perlakuan ada 4 yaitu :

$\mathrm{K} 1 \mathrm{M} 0$ :200 kg KCl ha ${ }^{-1}$ dan 0 kg Pupuk Mikro ha ${ }^{-1}$

K1M1 :200 kg KCl ha-1 dan $20 \mathrm{~kg}$ Pupuk Mikro ha ${ }^{-1}$

K2M0 :300 kg KCl ha ${ }^{-1}$ dan 0 kg Pupuk Mikro ha ${ }^{-1}$

K2M1 :300 kg KCl ha-1 dan $20 \mathrm{~kg}$ Pupuk Mikro ha- ${ }^{-1}$

Masing-masing perlakuan terdiri atas 3 ulangan sehingga terdapat 12 satuan percobaan. Pada setiap plot percobaan akan diambil 4 sampel tanaman yang akan digunakan sebagai sampel pengamatan. Setelah data didapatkan, akan diuji homogenitas ragam dengan uji Bartlett, selanjutnya dilakukan uji aditivitas data dengan uji Tukey. Bila kedua asumsi terpenuhi, dilakukan analisis ragam. Apabila ada perbedaan perlakuan pada analisis ragam dilakukan uji Beda Nyata Terkecil (BNT) pada taraf $5 \%$. Untuk interaksi perbedaan nilai tengah antar perlakuan menggunakan Probably of different (PDIFF). Analisis data dilakukan dengan menggunakan program SAS 9.0. 


\section{HASIL DAN PEMBAHASAN}

Hasil rekapitulasi analisis ragam nilai kuadrat tengah komponen pertumbuhan dan komponen hasil disajikan pada Tabel 1. Hasil analisis ragam pada tabel yang telah disajikan menunjukkan adanya variasi pada tinggi tanaman umur 4, 5, 6 BST, bobot ubi per tanaman, dan panjang ubi akibat penambahan dosis KCl. Selanjutnya pemberian pupuk mikro juga menunjukkan adanya variasi pada tinggi tanaman umur 4 sampai 7 BST, bobot kering batang umur 7 BST, bobot ubi per tanaman dan diameter ubi. Kemudian Penambahan dosis $\mathrm{KCl}$ dan pemberian pupuk mikro bersinergi pada komponen pertumbuhan, hal ini ditunjukkan dengan adanya variasi tinggi tanaman umur 4 sampai 7 BST, namun penambahan dosis $\mathrm{KCl}$ dan pemberian pupuk mikro tidak menunjukkan adanya variasi komponen ubi.

Tabel 1. Rekapitulasi Kuadrat Tengah Akibat Penambahan Pupuk $\mathrm{KCl}$ dan Pupuk Mikro

\begin{tabular}{|c|c|c|c|c|c|c|c|}
\hline Variabel & Rataan & Kelompok & $\mathrm{KCl}$ & PM & KClxPM & Galat & KK \\
\hline \multicolumn{8}{|c|}{ Komponen Pertumbuhan } \\
\hline TT 4 BST (cm) & 137,66 & 619,92 & $6.024,43^{* *}$ & $4.730,17 *$ & $2.001,38^{*}$ & 320,39 & 13,00 \\
\hline TT 5 BST (cm) & 163,20 & $3.015,74 * *$ & $6.963,93 * *$ & $11.117,27 * *$ & $3.739,55^{*}$ & 584,47 & 14,81 \\
\hline TT 6 BST $(\mathrm{cm})$ & 196,72 & $3.551,31 *$ & $3.075,59 *$ & $22.904,01$ *** & $5.954,53 * *$ & 746,91 & 13,89 \\
\hline TT 7 BST (cm) & 219,87 & $5.455,76^{\text {* } * \text { * }}$ & $1.810,98$ & $38.653,63^{* * *}$ & $8.345,91$ *中. & 916,27 & 13,77 \\
\hline JD 4 BST (helai) & 88,38 & $2.551,00^{*}$ & $1.408,33$ & 690,08 & 341,33 & 568,51 & 26,98 \\
\hline JD 5 BST (helai) & 96,27 & $2.738,90 *$ & $1.054,69$ & 652,69 & 266,02 & 571,48 & 24,83 \\
\hline JD 6 BST (helai) & 100,77 & $5.796,58 *$ & 414,19 & $2.067,19$ & 247,52 & $1.374,96$ & 36,80 \\
\hline JD 7 BST (helai) & 165,60 & $3.136,52$ & $2.067,19$ & $6.888,02$ & $5.187,52$ & $8.304,99$ & 55,03 \\
\hline BKB 7 BST (g) & 230,44 & $2.374,16$ & $7.237,34$ & $39.090,67 * *$ & $5.954,11$ & $1.810,45$ & 18,46 \\
\hline BKP 7 BST (g) & 30,75 & 183,79 & 142,83 & 11,21 & 218,45 & 162,39 & 41,44 \\
\hline BKD 7 BST (g) & 131,05 & $1.823,16$ & $9.042,03$ & $2.112,05$ & $1.624,01$ & $5.110,11$ & 54,55 \\
\hline BU 7 BST (g) & $1.716,67$ & $243.333,33$ & $853.333,33^{*}$ & $750.000,00^{*}$ & $213.333,13$ & $188.888,89$ & 20,09 \\
\hline PU 7 BST (g) & 23,32 & 20,70 & $375,52 *$ & 187,08 & 137,74 & 87,17 & 40,04 \\
\hline DU 7 BST (g) & 32,90 & 47,29 & 0,36 & $471,04 * *$ & 2,01 & 59,64 & 23,47 \\
\hline J 7 BST (buah) & 13,83 & 47,58 & 27,00 & 27,00 & 40,33 & 12,69 & 25,76 \\
\hline KP 7 BST ( $\%)$ & 14,92 & 1,58 & 4,08 & 4,08 & 4,08 & 2,25 & 10,06 \\
\hline \multirow[t]{6}{*}{ Kelerangan : } & \multicolumn{4}{|c|}{$*=$ berbeda nyala taraf $5 \%$} & \multicolumn{2}{|c|}{ JD = jumlah daun } & \\
\hline & \multicolumn{3}{|c|}{ *** = berbeda nyala taraf $1 \%$} & pupuk KCl & \multicolumn{2}{|c|}{ PM = pupuk mikro } & \\
\hline & \multicolumn{2}{|c|}{ BST = bulan setelah tanam } & $\mathrm{DU}=$ & = diameler ubi & \multicolumn{2}{|c|}{$\mathrm{JU}=$ jumlah ubi } & \\
\hline & \multirow{2}{*}{\multicolumn{3}{|c|}{$\begin{array}{l}\text { BU = bobol ubi per tanaman } \\
\text { BKB = bobol kering batang }\end{array}$}} & = kadar pali & & & \\
\hline & & & $\mathrm{BKP}=$ & $=$ bobol kering & petiol & & \\
\hline & \multicolumn{2}{|c|}{$\mathrm{BKD}=$ bobol kering daun } & $\mathrm{KxPI}$ & $=$ interaksi pu & unuk KCI da & puk mikro & \\
\hline
\end{tabular}


Hasil penelitian menunjukkan bahwa penambahan dosis $\mathrm{KCl}$ berpengaruh nyata terhadap tinggi tanaman ubukayu pada umur 4 sampai 6 BST namun pada umur 7 BST tidak berbeda nyata (Tabel 2). Berdasarkan uji beda nyata terkecil (BNT) 5\% tanaman ubikayu yang diaplikasikan dosis $200 \mathrm{~kg}$ pupuk $\mathrm{KCl} \mathrm{ha}{ }^{-1}$, pada tinggi tanaman secara berturut-turut memiliki rata-rata tinggi tanaman $(145,64 \mathrm{~cm})$ $(171,69 \mathrm{~cm})(202,98 \mathrm{~cm})(224,16 \mathrm{~cm})$ yang lebih tinggi dibandingkan tanaman ubikyu yang diaplikasikan dosis pupuk $\mathrm{KCl}$ yang lebih tinggi yaitu $300 \mathrm{~kg}$ pupuk $\mathrm{KCl} \mathrm{ha}{ }^{-1}$ rata-rata tinggi tanaman $(128,90 \mathrm{~cm})$ $(153,88 \mathrm{~cm})(190,98 \mathrm{~cm})(215,17 \mathrm{~cm})$ pada umur 4 sampai 6 BST.

Tabel 2. Pengaruh penambahan $\mathrm{KCl}$ terhadap tinggi tanaman ubikayu

\begin{tabular}{cccc}
\hline \multirow{2}{*}{ Variabel Pengamatan } & \multicolumn{2}{c}{ Dosis Pupuk KCl (kg/ha) } & \multirow{2}{*}{ BNT (5\%) } \\
\cline { 2 - 3 } & 200 & 300 & \\
\hline Tinggi Tanaman 4 BST & $145,64 \mathrm{a}$ & $128,90 \mathrm{~b}$ & 7,69 \\
Tinggi Tanaman 5 BST & $171,69 \mathrm{a}$ & $153,88 \mathrm{~b}$ & 10,39 \\
Tinggi Tanaman 6 BST & $202,98 \mathrm{a}$ & $190,92 \mathrm{~b}$ & 11,74 \\
Tinggi Tanaman 7 BST & $224,16 \mathrm{a}$ & $215,17 \mathrm{a}$ & 13,01 \\
\hline
\end{tabular}

Keterangan : Angka yang diikuti huruf yang sama pada baris yang sama menunjukkan tidak ada perbedaan nilai tengah yang nyata pada uji lanjut beda nyata terkecil $(\mathrm{BNT}) 5 \%, \mathrm{BST}=$ bulan setelah tanam.

Kemudian pada pemberian pupuk mikro hasil penelitian juga menunjukkan bahwa pemberian pupuk mikro berpengaruh nyata terhadap tinggi tanaman ubikayu pada umur 4 sampai 7 BST (Tabel 3). Berdasarkan uji beda nyata terkecil (BNT) 5\% tanaman ubikayu yang diaplikasikan dosis $20 \mathrm{~kg}$ pupuk mikro ha-1, pada tinggi tanaman secara berturut-turut memiliki rata-rata tinggi tanaman $(145,35 \mathrm{~cm})(174,91 \mathrm{~cm})$ $(213,35 \mathrm{~cm})(241,37 \mathrm{~cm})$ lebih tinggi dibandingkan tanpa pemberian pupuk mikro rata-rata tinggi tanaman $(129,98 \mathrm{~cm})$ $(151,49 \mathrm{~cm})(180,09 \mathrm{~cm})(198,37 \mathrm{~cm})$ pada umur 4 sampai 7 BST.
Tabel 3. Pengaruh pemberian pupuk mikro terhadap tinggi tanaman ubikayu

\begin{tabular}{cccc}
\hline \multirow{2}{*}{ Variabel Pengamatan } & \multicolumn{2}{c}{ Dosis Pupuk Mikro (kg gha) } & \multirow{2}{*}{ BNT (5\%) } \\
\cline { 2 - 3 } & 0 & 20 & \\
\hline Tinggi Tanaman 4 BST & 129,98 a & 145,35 a & 7,68 \\
Tinggi Tanaman 5 BST & 151,49 a & 174,91 a & 10,38 \\
Tinggi Tanaman 6 BST & 180,09 a & 213,35 a & 11,73 \\
Tingoi Tanaman 7 BST & $198,37 \mathrm{~b}$ & $241,37 \mathrm{a}$ & 12,99 \\
\hline
\end{tabular}

Keterangan : Angka yang diikuti huruf yang sama pada baris yang sama menunjukkan tidak ada perbedaan nilai tengah yang nyata pada uji lanjut beda nyata terkecil (BNT) $5 \%$, BST = bulan setelah tanam.

Kemudian interaksi dari penelitian menunjukkan bahwa penambahan dosis $\mathrm{KCl}$ dan pemberian pupuk mikro berpengaruh nyata terhadap tinggi tanaman umur 4 sampai 7 BST (Gambar 1). Berdasarkan uji beda nyata terkecil (BNT) $5 \%$ aplikasi dosis pupuk $200 \mathrm{~kg} \mathrm{KCl} \mathrm{ha-1}$, pada tinggi tanaman memiliki rata-rata tinggi tanaman lebih tinggi akibat pemberian pupuk mikro dibandingkan tanpa pupuk mikro pada umur 4 sampai 7 BST (Gambar 1). Sebaliknya pada dosis pupuk $\mathrm{KCl}$ yang lebih tinggi yaitu $300 \mathrm{~kg}$ $\mathrm{KCl} \mathrm{ha}{ }^{-1}$, pada tinggi tanaman tidak berbeda nyata antara aplikasi pupuk mikro dan tanpa pupuk mikro.

Perbandingan dosis pupuk $\mathrm{KCl}$ antara $200 \mathrm{~kg} \mathrm{KCl} \mathrm{ha}^{-1}$ dan $300 \mathrm{~kg} \mathrm{KCl} \mathrm{ha}^{-1}$ yang diaplikasikan $20 \mathrm{~kg}$ pupuk mikro $\mathrm{ha}^{-1}$. Dosis $200 \mathrm{~kg} \mathrm{KCl} \mathrm{ha}^{-1}$ dengan aplikasi 20 $\mathrm{kg}$ pupuk mikro ha ${ }^{-1}$ pada variabel tinggi tanaman memiliki rata-rata tinggi tanaman yang lebih tinggi dibandingkan dosis pupuk $\mathrm{KCl}$ yang lebih tinggi yaitu $300 \mathrm{~kg} \mathrm{KCl}^{-}$ ${ }^{1}$ dengan $20 \mathrm{~kg}$ pupuk mikro ha ${ }^{-1}$. Secara umum perlakuan pupuk $200 \mathrm{~kg} \mathrm{KCl} \mathrm{ha}{ }^{-1}$ dan $20 \mathrm{~kg}$ pupuk mikro ha ${ }^{-1}$ memiliki ratarata tinggi tanaman yang lebih tinggi, sedangkan rata-rata tinggi tanaman ubikayu terendah pada umur 4 sampai umur 7 BST disebabkan perlakuan pupuk $200 \mathrm{~kg} \mathrm{KCl}$ ha $^{-1}$ dan tanpa aplikasi pupuk mikro. 


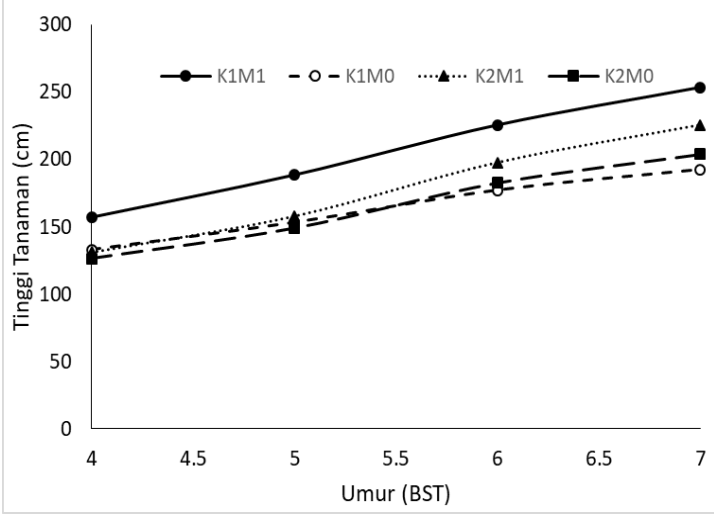

Gambar 1. Grafik Pertumbuhan Tinggi Tanaman Ubikayu pada umur 4 sampai 7 BST Akibat Penambahan Pupuk $\mathrm{KCl}$ dan Pemberian pupuk Mikro.

Selanjutnya pada variabel pengamatan jumlah daun pada umur 4 sampai 7 BST akibat penambahan pupuk $\mathrm{KCl}$ dan pemberian pupuk mikro tidak berpengaruh nyata hal ini dapat terlihat pada Tabel 1 . Nilai kuadrat tengah jumlah daun tidak menunjukkan adanya variasi baik pada penambahan pupuk $\mathrm{KCl}$ maupun pada pemberian pupuk mikro serta interaksi keduanya. Kemudian pada variabel bobot brangkasan, hasil penelitian menunjukkan bahwa penambahan pupuk mikro berpengaruh nyata pada bobot kering batang, penambahan pupuk mikro $20 \mathrm{~kg} \mathrm{ha}^{-}$ 1 secara umum meningkatkan rata-rata bobot kering batang 287,52 g lebih besar dibandingkan tanpa pupuk mikro 173,37 $\mathrm{g}$ (Gambar 2).

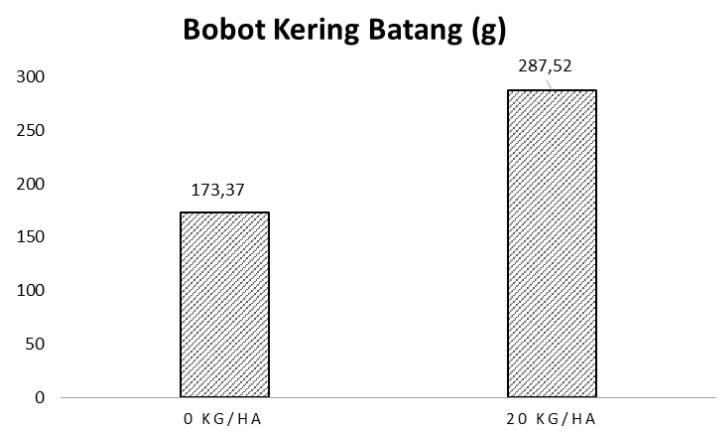

Gambar 2. Bobot brangkasan tanaman ubikayu akibat pemberian pupuk mikro dan tanpa pupuk mikro.
Selanjutnya pada komponen ubi penambahan dosis $\mathrm{KCl}$ pada tanaman ubikayu berpengaruh nyata variabel bobot ubi per tanaman dan panjang ubi umur 7 BST (Gambar 3). Bobot ubi per tanaman yang diaplikasikan $300 \mathrm{~kg} \mathrm{KCl}$ ha $^{-1}$ menghasilkan rata-rata bobot ubi per tanaman (1.983,3 g) yang lebih besar dibandingkan $200 \mathrm{~kg} \mathrm{KCl} \mathrm{ha}{ }^{-1}$ rata-rata bobot ubi per tanaman $(1.450,0 \mathrm{~g})$, begitu juga dengan panjang ubi yang diberi $300 \mathrm{~kg}$ $\mathrm{KCl} \mathrm{ha}{ }^{-1}$ menghasilkan rata-rata panjang ubi $25,15 \pm 10,78 \mathrm{~cm}$ yang lebih panjang dibandingkan $200 \mathrm{~kg} \mathrm{KCl} \mathrm{ha}{ }^{-1}$ rata-rata panjang ubi $21,27 \pm 7,38 \mathrm{~cm}$.

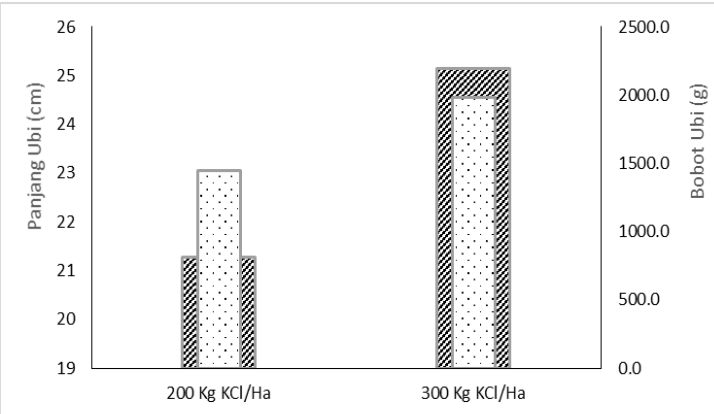

Gambar 2. Bobot ubi dan panjang ubi tanaman ubikayu akibat penambahan pupuk $\mathrm{KCl}$.

Keterangan : Kotak yang diarsir warna hitam menunjukkan variabel panjang ubi sedangkan kotak yang diarsir warna putih menunjukkan varialbel bobot ubi.

Selanjutnya pemberian $20 \mathrm{~kg}$ pupuk mikro ha ${ }^{-1}$ berpengaruh nyata pada variabel bobot ubi per tanaman umur 7 BST dan diameter ubi umur 7 BST (Tabel 1). Bobot ubi per tanaman umur 7 BST yang diaplikasikan $20 \mathrm{~kg}$ pupuk mikro hamenghasilkan rata-rata bobot ubi $(1.966,70$ g) yang lebih besar dibandingkan tanpa aplikasi mikro $(1.466,70 \mathrm{~g})$ begitu juga dengan diameter ubi 7 BST yang diberi 20 $\mathrm{kg}$ pupuk mikro ha ${ }^{-1}$ menghasilkan rata-rata diameter $35,16 \pm 8,45 \mathrm{~mm}$ yang lebih besar dibandingkan $0 \mathrm{~kg}$ pupuk mikro ha ${ }^{-1}$ ratarata diameter ubi $30,73 \pm 6,69 \mathrm{~mm}$. 


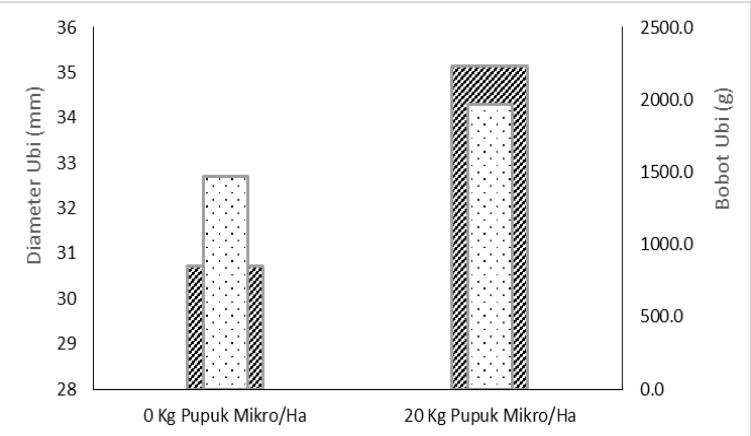

Gambar 2. Bobot ubi dan diameter ubi tanaman ubikayu akibat pemberian pupuk mikro.

Keterangan : Kotak yang diarsir warna hitam menunjukkan variabel diameter ubi sedangkan kotak yang diarsir warna putih menunjukkan variabel bobot ubi.

Pada pengukuran tinggi tanaman ubikayu umur 4 sampai 7BST (Gambar 1). Aplikasi $20 \mathrm{~kg}$ pupuk mikro ha ${ }^{-1}$ dan dosis $200 \mathrm{~kg} \mathrm{KCl} \mathrm{ha}{ }^{-1}$ menghasilkan tinggi tanaman yang lebih tinggi dibandingkan tanpa aplikasi pupuk mikro. Namun pada dosis pupuk $\mathrm{KCl}$ yang lebih tinggi yaitu 300 $\mathrm{kg} \mathrm{KCl} \mathrm{ha}{ }^{-1}$ dan $20 \mathrm{~kg}$ pupuk mikro ha ${ }^{-1}$ pada tinggi tanaman tidak berbeda nyata dengan $300 \mathrm{~kg} \mathrm{KCl} \mathrm{ha}^{-1}$ dan tanpa aplikasi pupuk mikro. Hal ini diduga penambahan dosis $\mathrm{KCl}$ yang tinggi tanpa dibarengi unsur hara makro lainnya seperti $\mathrm{N}$ dan $\mathrm{P}$ menyebabkan pertumbuhan tidak maksimal. Hasil penelitian Ispandi (2003), menunjukkan bahwa pemberian unsur kalium dengan berbagai dosis pada tanaman ubikayu tidak berpengaruh nyata pada tinggi tanaman. Unsur $\mathrm{K}$ sangat diperlukan dalam pembentukan, pembesaran dan pemanjangan umbi namun tidak terlalu berpengaruh dalam pertumbuhan tanaman ubikayu, unsur hara yang sangat berperan dalam pertumbuhan tanaman ialah N (Howeler, 1981).

Selanjutnya pada variabel bobot kering batang, petiol dan daun yang diberi aplikasi pupuk mikro bobot kering tanaman menunjukkan adanya pengaruh nyata. Parameter tinggi tanaman diduga berpengaruh terhadap besarnya bobot kering tanaman. Sitompul dan Guritno (1995), menyatakan bahwa tinggi tanaman berbanding lurus dengan bobot kering yang dihasilkan. Tanaman yang tinggi akan diikuti bobot kering yang besar. Semakin tua umur panen maka bobot kering tanaman semakin besar hal ini disebabkan karena meningkatnya kadar serat dan berkurangnya kadar air tanaman. Bobot kering tanaman mencerminkan status nutrisi tanaman, besar kecilnya bobot kering tergantung dari serapan unsur hara dan laju fotosintesis selama berlangsungnya proses pertumbuhan tanaman (Salisbury dan Ross, 1995).

Kemudian pada komponen hasil peningkatan pupuk $300 \mathrm{KCl} \mathrm{kg} \mathrm{ha}^{-1}$ mampu meningkatkan bobot ubi per tanaman pada umur 7 BST dibandingkan aplikasi pupuk $200 \mathrm{KCl} \mathrm{kg} \mathrm{ha}{ }^{-1}$. Kemudian untuk pemberian pupuk $20 \mathrm{~kg}$ pupuk mikro ha ${ }^{-1}$ juga mampu memberikan peningkatan terhadap bobot ubi per tanaman pada umur 7 BST dibandingkan tanpa pemberian pupuk mikro. Peningkatan bobot ubi per tanaman umur 7 BST didukung oleh ukuran ubi yaitu panjang dan diameter ubi. Aplikasi 300 pupuk $\mathrm{KCl} \mathrm{kg} \mathrm{ha}^{-1}$ berpengaruh nyata terhadap panjang ubi pada umur 7 BST namun pada diameter ubi tidak berbeda nyata. Sedangkan pemberian $20 \mathrm{~kg}$ pupuk mikro ha ${ }^{-1}$ berpengaruh nyata pada diameter ubi umur 7 BST.

Pemberian unsur kalium diduga merangsang pemanjangan akar sehingga menghasilkan ubi yang lebih panjang. Sedangkan tanaman ubikayu yang diberi pupuk mikro memiliki diameter yang lebih besar. Hal diduga karena tanaman ubikayu yang diaplikasikan memiliki hasil fotosintat yang cukup banyak untuk didistribusikan ke ubi. Sejalan dengan hal tersebut Widodo (1990) mengemukakan ubi yang panjang umumnya tidak berdiameter besar begitupun sebaliknya ubi yang berdiameter 
besar tidak memanjang. Unsur hara mikro seperi $\mathrm{Cu}, \mathrm{Fe}$, dan $\mathrm{Zn}$ berperan penting dalam laju fotosintesis, kekurangan unsur mikro ini akan menghambat laju fotosintesis dalam menghasilkan fotosintat (Rosmarkam dan Yuwono, 2002). Diameter ubi sendiri terbentuk karena terjadinya penggelembungan akar akibat hasil fotosintat yang ditranslokasikan ke pembentukan ubi. Menurut Widodo (1990), terbentuknya ubi karena terjadinya penimbunan fotosintat dari daun yang didistribusikan ke ubi sehingga membentuk ubi. Selain itu, pembentukan ubi juga dipengaruhi oleh ketersedian unsur hara yang digunakan dalam proses fotosintesis. Secara fisiologis, tanaman ubikayu tidak mungkin dapat menumbuhkan semua ubi menjadi besar jika tanaman tersebut tidak dapat menyediakan unsur hara yang cukup dan seimbang untuk perkembangan ubi.

Unsur hara kalium berperan besar dalam proses peningkatan produksi ubi pada budidaya tanaman ubikayu. Peran kalium sendiri di antaranya menjaga tekanan turgor agar sel tanaman mampu mempertahankan kekokohan sehingga memberi tanaman kemampuan untuk berdiri tegak. Kalium juga mengatur membuka dan menutupnya stomata, di mana ketika stomata membuka akan memudahkan $\mathrm{CO}_{2}$ berdifusi secara cepat ke daun. Hal ini meningkatkan laju fotosintesis sehingga karbohidrat banyak tersedia untuk pertumbuhan (Taufiq, 2014). Hasil penelitian Sianturi dan Ernita (2014), menunjukkan bahwa tanaman yang diberi unsur kalium berpengaruh lebih baik terhadap jumlah ubi dan bobot ubi per tanaman. Hal ini terjadi karena kalium berperan pada proses translokasi fotosintat ke dalam ubi, sehingga mempengaruhi pengisian bobot ubi. Selain itu, hasil penelitian Balitkabi (2015), menunjukkan pemberian unsur kalium pada tanah masam di Lampung meningkatkan kandungan pati sebesar $2-4 \%$ pada beberapa varietas ubikayu.
Unsur hara lain yang terangkut melalui panen serta hampir tidak pernah diperhatikan, ialah unsur hara mikro. Unsur hara mikro memiliki peran penting seperti unsur hara makro, walaupun kebutuhan akan unsur hara mikro relatif rendah. Sebagai contoh Fe (Besi) berfungsi sebagai katalisator atau bagian dari sistem enzim yang berkaitan dalam pembentukan klorofil. Hal ini didukung oleh hasil penelitian Zuhaida et al. (2013), yang menyatakan bahwa pemberian 6,0 ppm konsentrasi $\mathrm{Fe}$ mampu meningkatkan bobot segar tanaman sekitar tiga kali lipat bobot segar total pada 1,5 ppm konsentrasi Fe. Sudaryono (2017), melaporkan bahwa pemberian hara $6 \mathrm{~kg}$ boron $\mathrm{ha}^{-1}$ pada ubi jalar mampu menghasilkan produksi umbi yang lebih baik dari $0 \mathrm{~kg}$ boron $\mathrm{ha}^{-1}$ ataupun $12 \mathrm{~kg}$ boron $\mathrm{ha}^{-1}$, meningkatnya dosis pemberian boron justru menurunkan performa tumbuhan. Berdasarkan uraian di atas maka dilakukan penelitian pemberian unsur hara mikro pada ubikayu karena masih sangat jarang penelitan ubikayu yang berkaitan dengan hara mikro.

Unsur hara mikro sangat dibutuhkan untuk pertumbuhan dan perkembangan tanaman ubikayu, walaupun jumlah unsur hara mikro yang dibutuhkan tanaman ubikayu sangatlah sedikit tetapi tetap harus terpenuhi, karena unsur hara mikro memiliki peranan yang sangat penting bagi proses pertumbuhan dan produksi tanaman ubikayu. Salah satu peran unsur hara mikro yang sangat penting yaitu sebagai aktivator enzim sehingga proses metabolisme tanaman ubikayu berjalan optimum (Fageria et al., 2009). Metabolisme yang berjalan optimum pada ubikayu akan berdampak baik bagi pertumbuhan dan perkembangan ubikayu, sehingga tanaman ubikayu dapat menghasilkan kadar pati yang tinggi.

Pada penelitian ini kandungan pati pada tanaman ubikayu yang dipanen pada umur 7 BST tergolong masih rendah dan akan meningkat serta memiliki kandungan pati 
optimal bila dipanen lebih dari umur 7 BST. Panen yang melebihi umur optimal juga tidak baik karena akan menyebabkan penurunan kadar pati pada ubikayu, penurunan kadar pati ini diduga disebabkan oleh peningkatan komponen-komponen non pati seperti selulosa, hemiselulosa, pektin, dan lignin (Susilawati et al., 2008). Menurut Wargiono et al. (2006) menyatakan bahwa kadar pati dalam ubikayu akan cenderung meningkat dengan bertambahnya umur tanaman. Selain karena bertambahnya umur tanaman, kandungan pati juga dapat meningkat karena tercukupinya unsur hara yang dibutuhkan tanaman untuk melakukan fotosintesis, sehingga fotosintat yang dihasilkan dapat menjadi pati dalam ubi. Balai Penelitian Tanaman Aneka Kacang dan Umbi (2015) menyatakan bahwa tanaman ubikayu UJ-3 siap panen pada 8-10 BST dan memiliki kadar pati 20,00$27,00 \%$.

Abbot dan Harker (2001), menambahkan bahwa pada umumnya dengan bertambahnya tingkat ketuaan ubiubian akan semakin keras teksturnya karena kandungan pati yang semakin meningkat akan tetapi, apabila terlalu tua kandungan seratnya bertambah sedangkan kandungan pati menurun. Hubungan antara pemberian pupuk mikro dan kadar pati dijelaskan oleh Fageria et al. (2009), bahwa penambahan unsur hara $\mathrm{Zn}, \mathrm{Mg}$, dan $\mathrm{S}$ berpengaruh nyata pada kandungan pati ubi. Tanaman ubikayu yang diberi perlakuan tanpa $\mathrm{Zn}$ dan hanya diberi $\mathrm{Mg}$ dan $\mathrm{S}$ memiliki kadar pati 24,9\% dan apabila tanaman ubikayu diberi ketiganya unsur hara tersebut yaitu $\mathrm{Zn}, \mathrm{Mg}$ dan $\mathrm{S}$ maka kadar pati meningkat menjadi 28,5\%. Hal ini membuktikan bahwa pemberian pupuk mikro $\mathrm{Zn}$ sangat diperlukan bagi tanaman ubikayu untuk meningkatkan kadar pati.

Produksi ubikayu dapat ditingkatkan dengan menggabungkan beberapa teknologi budidaya tanaman. Penggunaan klon yang unggul jika dikombinasikan dengan penambahan unsur hara kalium yang banyak diserap tanaman karena perannya yang fungsional serta pemberian hara mikro yang dapat membantu proses biokimia tanaman akan dapat meningkatkan hasil produksi ubikayu. Oleh sebab itu, diyakini pemberian unsur kalium tambahan dan unsur mikro nantinya hasil penelitian ini dapat direkomendasikan dengan harapan meningkatkan hasil produksi ubikayu secara maksimal meskipun ubikayu dipanen muda.

\section{SIMPULAN}

Berdasarkan hasil penelitian, dapat disimpulkan bahwa:

1. Aplikasi $300 \mathrm{~kg} \mathrm{KCl} \mathrm{ha}{ }^{-1}$ menurunkan tinggi tanaman secara berturut-turut umur 4 sampai 6 BST $(145,64 \mathrm{~cm})$ $(171,69 \mathrm{~cm})(202,98 \mathrm{~cm})$ lebih rendah daripada $200 \mathrm{~kg} \mathrm{KCl} \mathrm{ha}{ }^{-1}(128,90 \mathrm{~cm})$ $(153,88 \mathrm{~cm})(190,98 \mathrm{~cm})$, sebaliknya pada komponen ubi, bobot ubi per tanaman 7 BST meningkat dari 1.450,00 g (200 kg KCl ha $\left.{ }^{-1}\right)$ menjadi $1.983,30 \mathrm{~g}$ $\left(300 \mathrm{~kg} \mathrm{KCl} \mathrm{ha}^{-1}\right)$.

2. Aplikasi $20 \mathrm{~kg}$ pupuk mikro $\mathrm{ha}^{-1}$ meningkatkan tinggi tanaman secara berturut-turut umur 4 sampai 7 BST $(145,35 \mathrm{~g})(174,91 \mathrm{~cm})(213,35 \mathrm{~cm})$ $(241,37 \mathrm{~cm})$ lebih tinggi tinggi dibandingkan $0 \mathrm{~kg}$ pupuk mikro ha ${ }^{-1}$ $(129,98 \mathrm{~cm})(151,49 \mathrm{~cm})(180,09 \mathrm{~cm})$ $(198,37 \mathrm{~cm})$, begitu pula bobot ubi per tanaman BST meningkat dari 1.466,70 g (0 kg pupuk mikro ha ${ }^{-1}$ ) menjadi 1.966, $70 \mathrm{~g}$ (20 kg pupuk mikro ha $\left.{ }^{-1}\right)$.

3 Terjadi sinergi antara $\mathrm{KCl}$ dan mikro pada tinggi tanaman umur 4 BST, aplikasi $200 \mathrm{~kg}$ pupuk $\mathrm{KCl} \mathrm{ha}^{-1}$ dengan $20 \mathrm{~kg}$ pupuk mikro ha ${ }^{-1}$ lebih tinggi $(157,26 \mathrm{~cm})$ dibandingkan $300 \mathrm{~kg}$ pupuk $\mathrm{KCl} \mathrm{ha}^{-1}$ dengan $20 \mathrm{~kg}$ pupuk mikro ha ${ }^{-1}$ $(131,14 \mathrm{~cm})$ akan tetapi aplikasi kedua dosis pupuk $\mathrm{KCl}$ dengan aplikasi kedua dosis pupuk pupuk mikro tidak berpengaruh pada komponen ubi. 


\section{DAFTAR PUSTAKA}

Abbot, J. A and F. R. Harker. 2001. Texture. The Horticulture and Food Research Intitute of New Zealand Ltd. New Zealand. 324p.

Balitkabi (Balai Penelitian Tanaman Aneka Kacang dan Umbi). 2015. Cara Meningkatkan Kandungan Pati Ubikayu.

www.balitkabi.litbang.pertanian.go.i d. Diakses pada tanggal 8 Oktober 2018.

BBPPTP (Balai Besar Pengkajian dan Pengembangan Teknologi Pertanian). 2012. Umbi-umbian Sumber Karbohidrat Pengganti Beras. Kementrian Pertanian. Bogor. 55 hlm.

FAO (Food and Agriculture Organization of the United Nations). 2017. Save and Growth : Cassava. www.fao.org. Diakses pada tanggal 8 Oktober 2018.

Fageria, N.K., M.P.B. Filho. A. Moreira, and C.M. Guimaraes. 2009. Foliar fertilization of crop plants. J. Plant Nutr 32: 1044-1064.

Fauziah, F., R. Wulansari, dan E. Rezamela, 2018. Pengaruh pemberian pupuk mikro $\mathrm{Zn}$ dan $\mathrm{Cu}$ serta pupuk tanah terhadap perkembangan Empoasca sp. pada areal tanaman teh. Jurnal Agricultura 29 (1) : 26-34.

Howeler, R. H. 1981. Mineral nutrition and fertilization of cassava. Centro International De Agriculture Tropical. Colombia. 52p.

Ispandi, A. 2003. Pemupukan P, K dan waktu pemberian pupuk $\mathrm{K}$ pada tanaman ubikayu di lahan kering vertiol. Jurnal Ilmu Pertanian 10(2) : $35-50$.
Marschner, H. 1986. Mineral Nutrition of Higher Plants. Academic Press. London. 674p

Pusdatin (Pusat Data dan Informasi Pertanian). 2016. Outlook : Komoditas Pertanian Sub Sektor Tanaman Pangan Ubikayu. Kementrian Pertanian. Jakarta. 59 hlm.

Rosmarkam, A. dan N. W. Yuwono. 2002. Ilmu Kesuburan Tanah. Kanisius. Yogyakarta. $244 \mathrm{hlm}$.

Saleh, N., Taufiq, A., Widodo, Y., dan Sundari, T. 2016. Pedoman Budidaya Ubikayu Di Indonesia. AARD-Press. Bogor. 75 hlm.

Salisbury, F. W., dan C. W. Ross. 1995. Fisiologi Tanaman Jilid 2 terjemahan Lukman dan Sumaryono. Institut Teknologi Bandung. Bandung.

Sarwar, M. 2011. Effect of zinc fertilizer application on the incidence of rice stem borers (Scirpophaga species) (Lepidoptera: Pyralidae) in rice (Oryza sativa L.) Crop. Journal of Cereals and Oilseeds 2 (5): 61-65.

Setiawan, K., U. Hasanudin., E. Yuliadi, dan M. S. Hadi. 2017. Cassava : Bibit, Produksi, Manfaat dan Pascapanen. Universitas LampungBalitbangda Lampung Tengah. Lampung. $104 \mathrm{hlm}$.

Sianturi, D.A. dan Ernita. 2014. Penggunaan pupuk $\mathrm{KCl}$ dan bokashi pada tanaman ubi jalar (Ipomoea batatas). Jurnal Dinamika Pertanian 29 (1) : 37-44.

Sitompul, S. M., dan B. Guritno. 1995. Analisis Pertumbuhan Tanaman. UGM Press. Yogjakarta. 
Subandi. 2013. Peran dan pengelolaan hara kalium untuk produksi pangan di Indonesia. Pengembangan Inovasi Pertanian 6 (1) :1-10.

Sudarmi. 2013. Pentingnya unsur hara mikro bagi pertumbuhan tanaman. Jurnal Widyatama 22(2):178-183.

Sudaryono, T. 2017. Respon tanaman bawang merah terhadap pemupukan boron. Jurnal Ilmu-Ilmu Pertanian Agrika 11(2) : 161-169.

Sulistianingrum, P. 2013. Pengaruh campuran pupuk organik dan anorganik Terhadap Tanaman Jahe ( Zingiber officinale). Skripsi. Universitas Muhammadiyah Surakarta.

Susilawati, S. Nurdjanah, dan S. Putri, 2008. Karakteristik sifat fisik dan kimia ubi kayu berdasarkan lokasi penanaman dan umur panen berbeda. Jurnal Teknologi Industri dan Hasil Pertanian 13(2): 59-72.

Sundary, T. 2010. Pengenalan Varietas Unggul dan Teknik Budidaya Ubikayu. Balai Penelitian Kacang Kacangan dan Umbi-Umbian. Malang. $12 \mathrm{hlm}$.

Taufiq, A. 2014. Identifikasi Masalah Keharaan Tanaman Kedelai. Balai Penelitian Tanaman Aneka Kacang dan Umbi. Malang. $34 \mathrm{hlm}$.

Wargiono, J., A. Hasanuddin. dan Suyamto. 2006. Teknologi Produksi Ubikayu Mendukung Industri Bioethanol. Puslitbangtan. Bogor. $42 \mathrm{hlm}$.

Widodo, Y. 1990. Keeratan Hubungan Antara Sifat Kuantitatif Pada Ubi Jalar. Balai Penelitian Tanaman Pangan. Malang.
Zuhaida, Laila, E. Ambarwati dan E. Sulistyaningsih. 2013. Pertumbuhan dan hasil selada (Lactuca sativa) hidroponik diperkaya Fe. Vegetalika 1(4) : 68-73.Industri Bioethanol. Puslitbangtan. Bogor. $42 \mathrm{hlm}$. 


\section{Halaman Kosong}

